\title{
The Experience among Patients with Bone Fractures during Traditional Massage Therapy (Topu Bara): A Phenomenology Study
}

\author{
La Rakhmat Wabula ${ }^{1^{*}}$ (iD \\ Endah Fitriasari ${ }^{1}$ (D) \\ Syahfitrah Umamity ${ }^{1}$ \\ Arindiah Puspa Windari² (iD \\ 1 Study Program of Bachelor and \\ Professional in Nursing, STIKes \\ Maluku Husada, Ambon 97128 \\ Maluku, Indonesia. \\ 2 Study Program of Diploma III in \\ Midwifery, STIKes Maluku Husada, \\ Ambon 97128, Maluku, Indonesia. \\ ${ }^{*}$ Correspondence: La Rakhmat \\ Wabula \\ Study Program of Bachelor and \\ Professional in Nursing, STIKes \\ Maluku Husada, Ambon 97128 \\ Maluku, Indonesia \\ Phone: 6285234026052 \\ Email: la.rakhmat.wabula.stikesmh@ \\ gmail.com
}

\begin{abstract}
Background: In Indonesia, traditional medicine called "Sangkal Putung" has become an alternative treatment for fractures. Broken-bones sufferers at any age, anywhere, and in any case go to "Sangkal Putung" and there is even a public hospital that provides surgical services. Especially in Maluku Province, there is a type of traditional massage therapy treatment called "Topu Bara".

Purpose: The study aimed to explore the experiences among patients with bone fractures during traditional massage therapy (Topu Bara).

Methods: A phenomenological study that used deep interviews was used from August to September 2021 The participant was taken by purposive sampling, adult aged 25 to 55 -years old, and were the second or more of healing series. Data originated from 15 participants. Interviews were recorded, transcribed verbatim, and Collaizi analysis.

Results: The results of the study found 7 themes, including causes of fracture, time events, action taken directly after inside, pain experiences during handling in therapy "Topu Bara", coping of the patients, pain management, and advice given by healer to other participants.

Conclusions: Most of them stated that safety and comfort were the priority for fracture healing. The concept of culture in the behavioral alteration of fracture healing can have on the participants.
\end{abstract}

Keywords: fracture; traditional healing; sangkal putung; topu bara; transcultural nursing

(C) The Author(s) 2022

http://dx.doi.org/10.55048/jpns.v1i1.9

e-ISSN 2827-8100

p-ISSN 2827-8496

Received : January 18, 2022

Revised : January 19, 2022

Accepted : January 20, 2022

Published: January 21, 2022

\section{(i) 8}

This is an Open Access article distributed under the terms of the Creative Commons Attribution-NonCommercial 4.0 International License.

\section{INTRODUCTION}

Fracture is a crucial problem that is difficult for health professionals to handle. Treatment failure often occurs so it is deemed necessary for proper treatment. Fractures have a high prevalence rate. Common causes of fracture are accidents traffic accidents, work accidents, and other accidents (Nadler et al., 2014). Worldwide, road injuries cause disproportionately more than 1.3 million deaths and many more disabilities each year (Yuniar \& Nasution, 2017). Based on studies conducted by (Mirhadi et al., 2013), the average incidence of fractures

Wabula, L. R., Fitriasari, E., Umamity, S., \& Windary, A, P. (2022). The Experience among Patients with Bone Fractures during Traditional Massage Therapy (Topu Bara): A Phenomenology Study. The Journal of Palembang Nursing Studies. 1(1):9-15. http://dx.doi.org/10.55048/ jpns.v1i1.9 
associated with traffic accidents was 14.5 and 4.2 per 100,000 people (Sugiharto et al., 2016).

According to the World Health Organization (WHO), India ranks first in the country with the highest number of deaths due to traffic accidents. Meanwhile, Indonesia ranks 5th (Sudayasa et al., 2018). Indonesia is reported to have experienced an increase in the number of traffic accidents by more than $80 \%$ (Darmawan, 2013). In Indonesia, the death toll from traffic accidents reaches 120 people per day (Akhrani \& Ardyaningrum, 2019). The prevalence of injury by province from 2007-2018 increased gradually with all age categories including in 2007 around ((Arie, 2017)7.5\%), increased in 2013 to $(8.2 \%)$, and lastly in 2018 increased to $(9.2 \%)$ (Roma, 2013). Injury events can occur anywhere, such as on roads, homes, neighborhoods, schools, or workplaces (Mirhadi et al., 2013). Traffic accidents according to 35 provinces and the highest characteristics are in the North Sulawesi region (3.5\%), and Maluku itself ranks 30th (2.0\%) (Kemenkes RI, 2018).

Fractures are indirectly treated by medical treatment. However, this is not following the reality in society (Agarwal-harding et al., 2015). Most people prefer alternative medicine, where they believe that massage therapy (topu bara) can solve the fracture problem in patients without surgery or plate placement. Massage is an effort to relax the stiff part of the muscle because it has not been moved for a long time before exercise therapy (Kautsar, 2018). The proportion of utilization of traditional health services in Indonesia is 31.4 percentile, and in the Maluku area is 14.5 percentile (Kemenkes $\mathrm{RI}, 2018$ ). While topu bara therapy is a typical name from the Maluku region which is one of the traditional therapies for patients with fracture problems, in the Java area it calls it a denial putting therapy (Maelissa et al., 2020).

In Indonesia, Sangkal putung therapy is still widely used in the community, this is supported by research in Central Java that people prefer to seek treatment for alternative treatments of Sangkal Putung compared to modern hospitals that are easily accessible, have advanced developments in orthopedic and radiological surgery (Kautsar, 2018). Based on the results of interviews conducted by researchers in February 2021, data from 3 participants showed that the reasons for participants who had experienced fractures and undergo massage therapy (topu bara) were due to the fast healing process, saturation and ineffective medical services, information related to this treatment was obtained from relatives/family. Based on the results of the interview, the researcher wanted to explore the experiences of fracture patients who underwent traditional massage therapy (topu bara) in Maluku Province.

\section{METHODS}

\section{Design}

We used is a phenomenological study using in-depth interviews. This methodology allowed researchers to explore the phenomenon (Yuniar \& Nasution, 2017) of fracture sufferers who decided to go to Traditional massage (Topu Bara) for fracture healing. These can be identified through clinical nursing problems and asking researchable questions (Suarilah et al., 2017). Likewise, (Sudayasa et al., 2018) suggest that self-interest can be the driving force needed to formulate research questions. To some extent, the practitioner then needs to identify and develop an interest in potential changes in practice problems, which are usually stimulated by patient preferences and dissatisfaction, quality improvement data, practitioner inquiries, evaluation data, or new research data (Mulyono, 2017).

\section{Participants and Setting}

For this study, participants were taken by purposive sampling. The inclusion criteria in this study included: Adults aged 25 to 55 years and ranked second or more in the series of healing visits. Exclusion criteria, namely: Those who do not have a history of fractures with a history of treatment at "Topu Bara". Data comes from 15 participants, recorded interviews, transcribed verbatim, and Collaizi analyzed.

\section{Ethical Consideration}

All of the participants gave their informed consent to be involved in this study. This study has been registered and it passed the research ethics committee of Health Research Ethics Commission of the Faculty of Nursing, STIKes Maluku Husada with letter number RK. 089/ KEPK/STIK/VIII/2021.

\section{Data Collection}

Participants were interviewed in "Topu Bara" while waiting for recovery and at home for 1 month. Before starting the interview, the researcher tried with two administrative staff of "Topu Bara" to get general information and have a link that connects with the researcher. 
By remembering the information and taking notes, the researcher then approached the "Topu Bara" patients to meet the target participants. After the meeting, the researcher then explained the aims and objectives of the research. Patient authority is prioritized. Patients who verbally agreed to participate in the study then consented to their legally confirmed participation as participants. Therefore, data collection with interviews conducted individually; several times depending on the needs of participants and has reached data saturation. All data taken from the interviews were recorded, transcribed, and validated by double-checking the participants. Thus, valid data are then analyzed.

\section{Data Analysis}

The data analysis method was adopted from Collaizi (1978) (Maelissa et al., 2020) as written below: Describing the phenomenon under study through trying to understand the phenomenon of the patient's experience. As well as coping strategies they adopt through the study of literature. In addition, researchers were trying to dive in and immerse themselves in a state of participant's experience taking alternative healing at "Topu Bara". Transcribing data interviews to be able to describe the experience of patients with fractures who came to "Topu Bara". Thus, collecting descriptions of the phenomenon through the opinion of participants. Reading those data two to three times thoroughly until able to understand the experience of patients. Additionally, read the entire description of the phenomena that have been submitted by participants. Understanding the experiences of the participants, it then continued to read the entire transcript of the interview and select statements are significant and following the particular goals for analysis. Signify typed data by re-read the statement and trying to find keywords that are the core of the statement. Studied every keyword then grouped them into categories. This followed by re-read the entire existing category, comparing and looking for similarities between these categories, and eventually grouping similar categories into themes. Passed through to the theme found over the data and wrote it into a description of the relevant experience of participants. Went back to the participants and asked participants to read the description of the study. This was done to determine whether the description that had been developed by researchers following the state of respondent's experience. Analyzed data that has been obtained during validation to the participants, and put it in the final description to enable the readers to recognize the experience of participants as they perceived during the fracture healing process at "Topu Bara".

\section{Trustworthiness}

Analyzed data that has been obtained during validation to the participants, and put it in the final description to enable the readers to recognize the experience of participants as they perceived during the fracture healing process at Topu Bara.

\section{RESULTS}

The participants of this research are described in Table 1. They are in the second and more visit to traditional massage therapy (topu bara) in Maluku Province. There are 7 themes identified from the results of qualitative data analysis collected through in-depth interviews, namely:

\section{Theme 1: Causes of Fracture}

Almost half of the participants had fractures by falls and traffic accidents.

"My father knew well the father of the healer. I was around ten when I fell from Mango's tree and my father took me here and I was satisfied with the result. My leg was normal after that (he exposed her right leg), I had no difficulties. Even though not all my extended family agreed to go to this Topu Bara (for fracture healing, another family member went to another traditional massage), I am sure this one is the most suitable for me". (Rj, 31-year-old with fractured left ankle).

\section{Theme 2: Time Events}

A small part of a participant experienced more than a year. Almost all of them were suffered a closed fracture less than 3 months ago. There was one of the participants experienced a fracture one week ago. Those participants were already getting treatment at the time of the interview was at their third visit. Although each visit always brought positive progress, i.e. the range of motion that extends and pain are reduced, but not denied that the pain was still present when the healer did massage. Overall, all those written above did not deter the participants to stop coming for treatment.

"I broke a bone in my left leg while

Wabula, L. R., Fitriasari, E., Umamity, S., \& Windary, A, P. (2022). The Experience among Patients with Bone Fractures during Traditional Massage Therapy (Topu Bara): A Phenomenology Study. The Journal of Palembang Nursing Studies. 1(1):9-15. http://dx.doi.org/10.55048/ jpns.v1i1.9 
Table 1. The Characteristics of Participants

\begin{tabular}{cccccc}
\hline Participants & Age & Sex & Employee Statute & Type of Fracture & Reason \\
\hline $\mathrm{Ab}$ & 54 & Female & Midwife & Right Hip & Traffic accident \\
$\mathrm{Jd}$ & 21 & Female & College student & Right knee & Fall \\
$\mathrm{Ds}$ & 37 & Female & Housewife & Right Carpus & Fall \\
$\mathrm{Da}$ & 47 & Male & Motorcycle taxis driver & Left Tibia & Traffic accident \\
$\mathrm{Gh}$ & 59 & Female & Civil servant & Left Clavicle & Traffic accident \\
$\mathrm{Hs}$ & 43 & Male & Army & Right ankle & Fall \\
$\mathrm{Jk}$ & 46 & Male & Government employees & Lumbar & Fall \\
$\mathrm{Gi}$ & 55 & Male & Fisherman & Right knee & Fall \\
$\mathrm{Dk}$ & 42 & Male & Fisherman & Right ankle & Fall \\
$\mathrm{Hn}$ & 33 & Male & Motorcycle taxis driver & Left Tibia & Traffic accident \\
$\mathrm{Mn}$ & 22 & Male & College student & Right Tibia & Traffic accident \\
$\mathrm{Rj}$ & 31 & Male & Nurse & Left ankle & Fall \\
$\mathrm{Hi}$ & 46 & Male & Fisherman & Left Tibia & Traffic accident \\
$\mathrm{Bd}$ & 27 & Female & Housewife & Right Hip & Traffic accident \\
$\mathrm{Hi}$ & 34 & Male & Fisherman & Left Tibia & Traffic accident \\
\hline
\end{tabular}

working as a motorcycle taxi driver since

32 months ago, when I was driving

a motorcycle when it hit a tree" (Da,

47-year-old with fractured Left Tibia).

\section{Theme 3: Almost Taken Directly}

\section{After Inside}

Almost no participant went directly to the traditional massage therapy (topu bara) where was interview taken, at the time after the incident for healing. One participant went straight to the other the traditional massage therapy (topu bara). Most headed to the hospital. Less than half of them rushed to the traditional massage therapy (topu bara) after being less satisfied with the handling of service and they got suggestions to the traditional massage therapy (topu bara) precisely by the physician.

"This was not my first experience going to Topu Bara to get treatment for my clavicle; I had gone to another Traditional massage. It seemed I was a Topu Bara's adventure..hahaha (laugh). I heard too many suggestions so I compared what my friend said and which one was the best based on my personal views. Finally, this Topu Bara helped me much". (Gh, 59-year-old with fracture left clavicle)

\section{Theme 4: Pain Experiences during Handling in Traditional Massage}

\section{Therapy (Topu Bara)}

Almost all participants said a similar statement when they began therapy/massage as a part of fracture treatment by healer at the traditional massage therapy (topu bara). Starting from the pain of mild to severe. One participant said that he combined the traditional massage therapy (topu bara) treatment with physiotherapy at one of the state hospitals. This respondent stated very significant progress in the healing process. The pain was present when the message was processed by the healer. However, pain can be reduced to the level of mild pain no longer after the massage is finished.

"That was a magic power or something like that. In my religion (Islam), a selected person may be given by Allah (God) that kind of ability; they were able to cure without medication. I heard the healer always start with prayer before and after doing massage." (Tn Da, 47year-old, fractured left tibia)

\section{Theme 5: Coping of The Patients}

Almost all the participants had positive responses to the treatment they got from traditional massage therapy (topu bara). There were no statements from the respondent that they would stop the treatment process any time when they had no intention to the outcome.

"Three days ago, after she finished (the healer) with massage, she told me that

Wabula, L. R., Fitriasari, E., Umamity, S., \& Windary, A, P. (2022). The Experience among Patients with Bone Fractures during Traditional Massage Therapy (Topu Bara): A Phenomenology Study. The Journal of Palembang Nursing Studies. 1(1):9-15. http://dx.doi.org/10.55048/ jpns.v1i1.9 
the bone was joined well. I was very grateful to hear that. I wish (now) she will inform me that the bone conjunctions were strengthening than before. My fracture is more difficult to be healed compared to others (because of that) I was suggested to immobile this knee. At home, my husband and sons help me with my daily needs." (Gi, 55-year-old, fractured right knee).

\section{Theme 6: Pain Management}

Medication such as painkillers oral was suggested by the healer. The healer informed the participant Name of the analgesic oral and topical to buy at the medication store. In addition, the healer was also recommended some multivitamins to support bone union and encourage avoiding certain foods.

"You must know this kind of analgesic? (she showed a blister of analgesic to reduce pain), feel free to ask all patients here (at Topu Bara), they should bring the similar thing." (Ds, 37-year-old with fracture right Carpus)

"Look! This ointment is burning my skin (showing his right hip). The healer recommended I to have this. I bought it from medicine store. It is limited, so the price was a bit expensive." (Ab, 54-yearold, fracture right hip)

\section{Theme 7: Advice is Given by Healer to Other Patients}

The first participant was advised by the healer to come to a physician first at the very beginning they arrived at traditional massage therapy (topu bara). Participants thought that traditional massage therapy (topu bara) was advisable because it did not only solve the problem of physical but also psychological and or spiritual caused by fracture Almost all of the participants declared that the severity of a fracture should be to a medical first before traditional massage therapy (topu bara).

"Before I went to "Topu Bara" for treatment, I was previously treated at a doctor. But after 2 months of treatment showed no cure. So I was advised by my family to try the treatment at "Topu Bara". Initially the therapist suggested that you must first believe that the fracture you experienced could heal after undergoing the "Topu Bara" treatment. Not allowed to undergo "Topu Bara" therapy at other therapists. Before treatment, the therapist first reads a prayer as a healing ritual" (Hs, 43-year-old, Right ankle).

\section{Discussion}

Traditional massage therapy (topu bara) as an alternative for fracture healing was recommended by family, relatives, and close friends. No one participant came to traditional massage therapy (topu bara) with her/his initiative. A positive statement from the previous has become a strong motivation to make a final decision regarding fracture healing. The healer as the center of the healing process of fracture at a Topu Bara practiced a supernatural approach through massage which was perceived by participants. They believed that every healer at Topu Bara had that kind of power.

They expressed that during this massage process, participants experience a pain sensation. To reduce pain, the healer recommended the name of painkiller oral and or topical. Although they did not exactly know the series of visits' need to have a bone recovery, all participants said that they want to get well soon so they follow what the healer suggested.

The healer sometimes informed the bone healing process after the massage finished. Everything that comes from the healer during the healing process was perceived positively by participants. Implicit in the results of interviews with sources of hope and advice conveyed such as others suffered the same fracture. Not merely because of lack of funds for treatment to medical treatment (Table 1) as written above, showed that all participants are financially independent, but they come to Topu Bara for various considerations and reasons.

Family, relatives, and close friends who suggested them for Topu Bara treatment were fully attention and follow the result of every visit. Further, during the waiting time for healing, most all participants talked to each other and shared their experiences (Maryam, 2017). Participants perceived that situation was not found in any hospital. This has been stated by (Akhrani \& Ardyaningrum, 2019) that perception is the major social aspect so that people are freed from using services of an alternative based on their perspectives. In addition, treatment by a healer at Topu Bara as perceived by the public works, partly states that cost was not relevant. Almost all of the respondents know their suitability and herb

Wabula, L. R., Fitriasari, E., Umamity, S., \& Windary, A, P. (2022). The Experience among Patients with Bone Fractures during Traditional Massage Therapy (Topu Bara): A Phenomenology Study. The Journal of Palembang Nursing Studies. 1(1):9-15. http://dx.doi.org/10.55048/ jpns.v111.9 
used techniques. Massage techniques and the sequence of respondents believed the herb is very useful in fracture healing.

Additionally, based on the background of participants; demographics, economic, religion and culture, and economic, they vary from middle to high economic level, Moslem, and Maluku Province. Further, even though the coverage of health insurance provided by Indonesia's government was fully funded for any hospital service, it does not replace the existence of Topu Bara.

Generally, participants are believed in the medical services, but they are also searching for an alternative treatment that did not only focus on the problem of physic as they perceived. (Sholihah, 2018) stated that negative perception makes public attitudes towards complementary medicine was also negative. This has been expressed by a participant that Topu Bara healer was able to provide a sense of confidence that they will be recovered. The spiritual characteristic was a basic that bridge the participant's expectation to the bone recovery. This was the less they got when going to the medical service.

\section{Conclusions}

It can be concluded that participants put safety and comfort on the priority when they decide to get help for fracture. Pain which is commonly expressed by people with fractures decreased effectively when painkillers combined with safe and comfortable atmosphere work in balance. At Topu Bara along the healing process, people with fractures experienced holistic care that combined multiple approaches of culture, cure, and care. Topu Bara as an alternative for fracture healing has been well developed from generation to generation. The benefits of Topu Bara as an alternative treatment for fractures have been widespread in various ethnic groups and levels of society in Indonesia. This research was conducted in Maluku Province as a reference for health services for Eastern Indonesia. Further studies are needed to be explored taking into account cultural values and ethical practices.

\section{Declaration of Interest}

None

\section{Acknowledgment}

None

\section{Funding}

None

\section{Data Availability}

None

\section{References}

Agarwal-harding, K. J., Meara, J. G., Greenberg, S. L. M., Hagander, L. E., Zurakowski, D., \& Dyer, G. S. M. (2015). Estimating the Global Incidence of Femoral Fracture from Road Traffic Collisions. J Bone Joint Surg Am., 97(31), 1-9.

Akhrani, L. A., \& Ardyaningrum, Y. (2019). Attitude Toward Complementary and Alternative Medicine (CAM) as Sangkal Putung Patient Satisfaction. Atlantis Press, 304(Acpch 2018), 26-29. https:// doi.org/10.2991/acpch-18.2019.6

Arie, M. J. H. (2017). Fracture Treatment by Bonesetters in Central Ghana: Patients Explain their Choices and Experiences. Tropical Medicine and International Health, 12(4), 564-574. https://doi. org/10.1111/j.1365-3156.2007.01822.x

Darmawan, R. (2013). Pengalaman, Usability, dan Antarmuka Grafis: Sebuah Penelusuran Teoritis. ITB Journal of Visual Art and Design, 4(2), 95-102. $\quad$ https://doi.org/10.5614/itbj. vad.2013.4.2.1

Kautsar, M. (2018). Study of Health-seeking Behavior Towards the Practice of Sangkal Putung for Bone Fracture and the Making of Medical Discrimination in Cikendung Village, Pemalang Regency, Central Java - Indonesia. KnE Social Sciences, 3(5), 388. https://doi. org/10.18502/kss.v3i5.2345

Kemenkes RI. (2018). Hasil Utama Riset Kesehata Dasar (RISKESDAS). Jakarta: Kemenkes.

Maelissa, S. R., Lesilolo, O. F., \& Molle, L. P. (2020). Persepsi Pasien Fraktur Terhadap Terapi Non Farmakologi Topu Bara. Molucca Medica, 12(4), 32-37. https://doi.org/10.30598/molmed.2020. v13.i2.32

Maryam, S. (2017). Strategi Coping: Teori Dan Sumberdayanya. JURKAM: Jurnal Konseling Andi Matappa, 1(2), 101. https://doi.org/10.31100/jurkam.v1i2.12

Mirhadi, S., Ashwood, N., \& Karagkevrekis, B. (2013). Factors Influencing Fracture Healing. Trauma, 15(2), 140-155. https://

Wabula, L. R., Fitriasari, E., Umamity, S., \& Windary, A, P. (2022). The Experience among Patients with Bone Fractures during Traditional Massage Therapy (Topu Bara): A Phenomenology Study. The Journal of Palembang Nursing Studies. 1(1):9-15. http://dx.doi.org/10.55048/ jpns.v111.9 
doi.org/10.1177/1460408613486571

Mulyono, N. (2017). Penelitian Praktek Pengobatan Tradisional Patah Tulang Sistem Cimande. Meida Litbangkes, VII.

Nadler, S. F., Weingand, K., \& Kruse, R. J. (2014). The Physiologic Basis and Clinical Applications of Cryotherapy and Thermotherapy for The Pain Practitioner. Pain Physician, 7(3), 395-399. https:// doi.org/10.36076/ppj.2004/7/395

Roma, S. (2013). Kualitas Hidup Klien yang Mengalami Fraktur Ekstremitas Bawah dengan Pemasangan Open Reduction Internal Fixation (ORIF). Journal of Chemical Information and Modeling, 53(9), 1689-1699.

Sholihah, S. (2018). Analisis Faktor Yang Mempengaruhi Pengambilan Keputusan Pada Pasien Cedera Muskuloskeletal Yang Memilih Berobat Ke Sangkal Putung Berdasarkan Pendekatan Teori Health Belief Model. In (Doctoral dissertation, Universitas Airlangga).

Suarilah, I., Panji Asmoro, C., Setya Wahyudi, A., \& Yasmara, D. (2017). Sangkal
Putung; As It Perceived By People With Musculoskeletal Fracture. Atlantis Press, 3(Inc), 48-51. https://doi.org/10.2991/ inc-17.2017.18

Sudayasa, I. P., Kusumawati, P. A., Paddo, J., Bittikaka, Y., Salam, N. M., \& Sahidin, I. (2018). Identifikasi Kajian Filosofis Penyehat Tradisional Pijat Patah Tulang. Teknologi Terapan Berbabsis Kearifan Lokal (SNT2BKL), 1(1), 570-580.

Sugiharto, F., Supriyono, S., \& Rasyad, A. (2016). Transfer of Knowledge Keterampilan Pengobatan Tradisional Pijat Sangkal Putung. Jurnal Pendidikan: Teori, Penelitian, Dan Pengembangan, 1(9), 1864-1868. https://doi. org/10.17977/jp.v1i9.6862

Yuniar, D. P., \& Nasution, Z. (2017). Perilaku Pemagang Pengobatan Sangkal Putung. Jurnal Pendidikan : Teori, Penelitian, Dan Pengembangan, 2(Sangkal Putung), 1656-1661.

Wabula, L. R., Fitriasari, E., Umamity, S., \& Windary, A, P. (2022). The Experience among Patients with Bone Fractures during Traditional Massage Therapy (Topu Bara): A Phenomenology Study. The Journal of Palembang Nursing Studies. 1(1):9-15. http://dx.doi.org/10.55048/ jpns.v111.9 